\title{
Birinci Dünya Savaşı öncesi Osmanlı İmparatorluğunda Yapılan Yabancı Yatırımlar ve Alınan Borçlarda Fransa'nın Rolü
}

The Role of France in Foreign Investments and Borrowings in the Ottoman Empire before the First World War

\section{Damla AYOĞLU DUMAN ${ }^{1}$}

Geliş tarihi: 27.08.2019, Kabul tarihi: 06.12.2019, Basım tarihi: 10.05.2020

\section{Öz}

Birinci Dünya savaşı öncesi sanayileşmiş ülkeler, demiryolu yapımı ve borç verme konusunda Osmanlı İmparatorluğu topraklarında ciddi bir rekabete girmiştir. Savaş öncesi İngiltere demiryolu yapımı konusunda gücünü kaybederken Almanya ile Fransa arasındaki rekabet artmıştır. Ancak Fransa yatırımlar konusunda liderliği elinden bırakmamıştır. Aynı şekilde Osmanlı Devletinin en çok borçlandığı ülke Fransa'dır. Bu çalışmada, Fransız Ekonomi ve Finans Bakanlığı arşiv belgelerinden yararlanılarak, bu dönemde Osmanlı topraklarında Fransız sermayedarlarının aldığı demiryolu imtiyazları, yaptıkları yatırımlar ve alınan dış borçlar açısından Fransa'nın rolü incelenmiştir.

Anahtar kelimeler: Osmanl İmparatorluğu, Fransa, demiryollar, dı̧s borçlar, yabancı yatirmlar

JEL Kodlar1: N00, N15

\begin{abstract}
Before the First World War, there was a serious competition among the industrialized countries in the territory of the Ottoman Empire in terms of railway construction and lending. In the pre-war, Britain lost its power to build railways on Ottoman territories, while competition between Germany and France increased. However, France has not lost its leadership in investments. Likewise, the country that the Ottoman Empire borrowed the most from was France. In this study, the role of France in terms of railway concessions, investments and foreign debts in the Ottoman territories was examined by using the archive documents of the French Ministry of Economy and Finance.
\end{abstract}

Keywords: Ottoman Empire, France, railways, foreign debt, foreign investments

JEL Codes: N00, N15

\section{Giriş}

Batı Avrupalı devletler Sanayi Devrimini gerçekleştirirken, Osmanlı İmparatorluğu ekonomik değişimi yakalayamamış ve bu sürecin içinde sanayi

\footnotetext{
1 Akdeniz Üniversitesi İ̈BF, Dr. Öğretim Üyesi ayoglu@akdeniz.edu.tr

https://orcid.org/0000-0003-0256-9025
} 
devrimini yakalayamamış bir ülke olarak yer almıştır. Sanayi Devrimini ilk yaşayan ülke olan İngiltere, daha sonra Fransa, İtalya ve 1888 sonrasında ise Almanya Osmanlı pazarında önemli yere sahip olmuşlardır. 1898 yılında Almanya'nın Osmanlı İmparatorluğu üzerindeki politik etkisi artmaya başlamıştır ve bu durum Fransa'y1 rahatsız etmiştir (Fulton,2005: 138).

$\mathrm{Bu}$ rekabette öne çıkan sanayileşmiş ülkelerden birisi de Fransa'dır. Birinci Dünya savaşından önce Fransa ekonomik olarak etkisini artırmaya çalışmış olsa da, Osmanlı imparatorluğunun bu ülke ile olan ekonomik ilişkileri, Kanuni Sultan Süleyman döneminde bu devlete verilen kapitülasyonlara kadar uzanmaktadır. Osmanlı Devletinde Fransız etkisi sadece ekonomik alanda değil askeri ve eğitim alanlarında da görülür.

Tanzimat liderlerinde de bu etkiyi hissetmek mümkündür. Öyle ki 1840'da Tanzimat'n ilanında ve uygulamasında önemli role sahip olan Hariciye Nazırı Mustafa Reşit Paşa "Her zaman Fransa'ya dönmüşüzdür. Çünkü onlar bizim reformlarımızı desteklemişlerdir" diye açıklamada bulunmuştur (Raccagni,1980:341).

Bu çalışmada Fransız Ekonomi ve Finans Bakanlığı arşiv belgelerinden yararlanılarak, Birinci Dünya Savaşı öncesi bu rekabet ortamında Fransa'nın nasil bir rolü olduğu incelenecektir. Fransa ile Osmanlı İmparatorluğunun ekonomik ilişkileri nasıl gelişmiştir ve Birinci Dünya savaşı öncesine gelindiğinde iki ülke arasındaki ekonomik ilişkiler ne durumdadır? 19. yüzyllın sonuna gelindiğinde Fransız sermayedarları Osmanlı topraklarında hangi yatırımları gerçekleştirmişlerdir? Bu soruları yanıtlamak için ilk bölümde Batılı devletlerin, Sanayi Devrimi sonrasi ekonomilerindeki gelişmeler ve pazar arayışları anlatılacaktır. İkinci bölümde incelenen dönemde Osmanlı Devletinin ekonomisinin durumu ve kapitalist devletlerle kurulan ilişkiler, imparatorlukta inşa edilen demiryolları ve alınan dış borçlar açısından incelenecektir. Bu çalışmanın literatüre katkısı, Birinci Dünya Savaşı öncesi iki ülke arasındaki ilişkilerin, Fransız Ekonomi ve Finans Bakanlı̆̆ arşiv belgelerinden yararlanılarak ortaya konulmasından kaynaklanmaktadır.

\section{Sanayi Devrimi sonrası Batı Avrupa'da ekonomik gelişim}

Sanayi Devrimi ilk olarak İngiltere'de başlamıştır. Bu devrim öncesinde, İngiltere uluslararası ticarette öne çıkmıştır. Aynı zamanda tarım alanında da gelişmeler yaşanmıştır. Artık köylüler kendi tüketimleri için değil pazar için üretim yapmaya başlamışlardır. Bu sayede sanayi gelişimiyle büyüyen kentler için gıda ihtiyacını gidermek sorun olmaktan çıkmıştır. İngiltere'de sanayi devrimi kırsal alanlarda üretilmeye başlanan pamuklu tekstille başlamış ve şehirlerde üretim yapan fabrikalarla yayılmıştır. Pamuklu tekstili, yünlü tekstil üretimi ve demir-çelik izlemiştir. 18. yüzyllın ortalarında el aletleri de gelişmeye başlamış yeni icatlar sayesinde üretim maliyetleri düşmüş, arz 
artmıştır. Bu gelişmeyi buhar gücüyle çalışan makineler izlemiştir. Teknolojik gelişmeler sonucu arzın artması karşısında küçük bir ada ülkesi olan İngiltere'nin iç talebi yetersiz kalmış ve hızlı şekilde dış pazarlara yönelmiş ve dış ticaretin büyüme oranları hızlı şekilde artmıştır. İngiltere'de dış ticaretin ylllık büyüme oranları 1760-1790 yılları arasında yüzde 1,8'den 1801-1831 döneminde yüzde 2,7’ye ve 1831-1861 arasında da yüzde 4,5'e çıkmıştır (Tezel, 2002:63).

$\mathrm{Bu}$ gelişme İngiltere ile sınırlı kalmamış Batı Avrupa ülkeleri de bu değişimi yakalamış ve ucuz maliyetle kitlesel üretim yapmaya başlamışlardır. 19. yüzyllın ikinci çeyreğine gelindiğinde Avrupa ülkeleri bir yandan mamul malları için pazarlar bulmaya, diğer yandan bol ve ucuz hammadde ve gida kaynakları elde etmeye çalışyorlardı. Bundan dolayı bu dönemde dünya ticaret hacminde önemli bir genişleme meydana gelmiştir. Yüzyllın daha sonraki dönemlerinde deniz ulaştırmacıllğında yaşanan teknolojik gelişmeler ticaretteki bu eğilimi hızlandırmıştır (Pamuk,2005a:3). Dış pazarlara doğru bu yayılma politikası ticaretle sınırlı kalmamıştır. Sanayileşmiş devletler kendi mallarını daha kolay satabilmek ve üretim için ihtiyaç duydukları hammaddelere ulaşabilmek için sanayi dönüşümünü tamamlayamamış ülkelerde demiryolları yapmaya başlamışlardır. Aynı zamanda bu ticareti arttırabilmek için bu bölgelere yoğun olarak borç verilmeye başlanmıştır. Böylelikle Kapitalist ülkeler hem kendi mamul malları için talep yaratmışlar hem de ellerinde biriken sermayeyi ihraç etmişlerdir. Sanayisini geliştiren Kapitalist ülkeler ile ekonomisi tarıma dayalı sanayi dönüşümünü gerçekleştirememiş ülkeler arasındaki fark hızla açılmaya başlamıştır.

19. yüzyılın ikinci yarısı, Batı Avrupa’nın tümüyle sanayi toplumu özelliği kazandığı bir dönemdir (Ortaylı, 2008:15). İngiltere'nin ardından öne çıan ülke Fransa olmuştur. Fransa 1852 yllından itibaren burjuvazinin desteği ile gelişen sanayi kuruluşlarında ürettiği mamul malları dış pazarlara satmaya başlamıştır. 1847 ile 1869 yılları arasında ticarette kullanılan buharlı gemilerin sayıs1 197'den 454'e çıkmıstır. Dış ticaretin gelişmesiyle halkın refahı da artmıştır. 1850 ile 1880 yılları arasında milli gelirin ikiye katlandığını tahmin etmek yanlış olmaz. Milli gelirdeki bu artışa rağmen, tasarrufların yatırıma dönüştürülmesi bir problem teşkil etmiştir. Bu nedenle 19. yüzyllın üçüncü çeyreğinde bu tasarruflar yurt dışı yatırımlarına yönelmiştir(Raccagni, agm: 339-340).

Osmanlı topraklarında 19. Yüzyllın son çeyreğinde önemli bir yere sahip olan Alman İmparatorluğu siyasi birliğini diğer bat1 Avrupa devletlerine göre geç tamamlamıştır. En büyük Alman devleti olan Prusya sayesinde birleşmiş ve Zollverein yani gümrük birliğini sağlamıştır. İç gümrüklerin kalkması sayesinde Alman Devletleri hızlı şekilde sanayileşmiştir. Devletlerin birleşmesiyle kurulan Alman İmparatorluğu 19. yüzyllın son çeyreğinde sömürge yarışına katılmıştır. Sömürge elde etmek konusunda Almanya bütün 
Dünya'da güçlü rakiplerle karşılaşmıştır (Güran, 2014:179-180). Özellikle dünyanın her yerinde dönemin ekonomik olarak en güçlü devleti olan İngiltere ile rekabete girişmiştir. Almanya 1880lerden sonra Osmanlı topraklarına yönelmiştir.

\section{Sanayi Devrimi sonrası Osmanlı İmparatorluğunda Ekonomik Durum}

Osmanlı'nın Batıya eklemlenme süreci Kapitülasyonlarla başlamıştır. Osmanlı Devleti başlangıçta Batı'da gelişen ticareti kendi topraklarından geçirip vergi alabilmek ve siyasi amaçlarla ayrıcalıklar vermiştir. Coğrafi keşifler ve uluslararası ticaretin gelişmesiyle Osmanlı topraklarından geçen ticaret yolları önemini kaybetmiş ve İmparatorluğun Doğu ile Avrupa arasındaki lüks madde ticaretindeki önemli rolü ortadan kalkmıştır. Avrupa'nın gida maddeleri (esas olarak tahıl) ve hammadde (pamuk, yün, ham ipek, boya maddeleri vb.) talebindeki artsşın yanı sıra ucuz mamul mallar arzının da çoğalması Osmanlı ticaretinde ve ekonomisinde bir dönüşüme sebep olmuştur. Kapitalist devletlerle artan ticaret ve bu ticaretin Avrupalı ticaret sermayesinin kontrolüne girmesi yerel zanaatları yok etmeye ve temel mallar ihracatını hızlandırmaya başladı(Kıray, 1995: 14-15). Zaman içinde, Osmanlı ekonomisi giderek gerilerken, Avrupalı devletlere verilen tavizler sebebiyle Osmanlı devleti ekonomisi üzerindeki kontrolünü kaybetmiş ve kapitülasyonlar koparılmış tek taraflı tavizlere dönüşmüştür. Kapitalist devletler kendi tüccarları için vergi indirimleri, tüccarın yerleşme özgürlüğü, kişisel vergilerden muaf tutulması, kendi yasalarına tabii olup Osmanlı yasalarının dışında kalması gibi tavizler koparmayı başarmışlardır. Önce kişilere verilen bu tavizler, daha sonra yabancı şirketleri kapsayacak şekilde genişletilmiştir (G. Kazgan, 2002:13-14).

1838 yllında imzalanan Balta Limanı anlaşmasıyla Osmanlı gümrükleri üzerindeki tüm haklarından vazgeçmiş ve pazarlarını önce İngiltere'ye ve daha sonra yaptığı benzer anlaşmalarla, tüm Kapitalist devletlere açmıştır. $\mathrm{Bu}$ anlaşma ile üretilen hammaddelerin ihracatı kolaylaşmıştır. Aynı zamanda devletin mali bunalıma girdiği dönemlerde dış ticaret üzerinden aldığı vergilerden de vazgeçilmiştir.

$\mathrm{Bu}$ durum Kırım savaşı sırasında Avrupa para piyasalarından borçlanmanın da yolunu açmıştır. 1860- 61 yıllarındaki mali bunalım ve Lübnan'la yaşanan siyasi bunalım sırasında Osmanlı Devleti ihracattan alınan gümrük vergilerini yüzde 1'e indiren değişiklik maddesini imzalamak zorunda kalmıştır. Bu oran Birinci Dünya Savaşına kadar değiştirilmemiştir. İthalattan alınan vergilerse Osmanlı yönetiminin gayretleriyle bir miktar artır1lmış, 1861'de yüzde 5'den yüzde 8'e, 1905'te yüzde 11'e ve 1908'de yüzde 15'e çıkarılmıştır (Pamuk, age:18-19). 
Tablo 1: Devletlerin Yatırım Sermayesi Payları

\begin{tabular}{|l|l|l|l|}
\hline Dönem & Fransa & Almanya & İngiltere \\
\hline $1880-1889$ & 38,2 & 0,3 & 48,1 \\
\hline $1900-1913$ & 48,3 & 20,6 & 22,2 \\
\hline
\end{tabular}

Kaynak: Ortaylı İlber, 2008, Osmanlı İmparatorluğu'nda Alman Nüfusu: 69

1880lerden itibaren İngiltere'nin ilgisi sömürgeleştirdiği Misır ve Hindistan topraklarına kaymış ve Osmanlı topraklarında Fransa ve Almanya rekabete girişmiştir. Bu çekişmede demiryolları ve bankacılık öne çıkmıstır (Ortayl1, age:68-69). Tablo 1'de Fransa, Almanya ve İngiltere'nin Osmanl1 pazarında doğrudan yatırımların paylarındaki değişim görülmektedir. 20. yüzyılın başında Fransa ve Almanya'nın yatırımlardaki payı artarken, İngiltere'nin doğrudan yatırımlarının payı azalmıştır.

\subsection{Osmanlı Devletinde İnşa Edilen Demiryolları}

Osmanlı Devleti'nin sanayileşmiş ülkelerle olan ticaretinin artmasında en önemli sebeplerden biri bu ülkeler tarafından yapılan demiryollarıdır. Ticaret hacmi arttıkça limanlarla, tarım ve tüketim merkezlerine giden yolların elverişli olmaması sorun yaratıyordu. Osmanlı'da geleneksel olarak taşımacilık develerle yapıllyordu ve Avrupalı sermayedarlar için bu maliyetleri arttıran bir sorundu. Bunun çözümü de demiryolları inşa ederek taşıma maliyetlerini düşürmek ve böylelikle hem tarımsal ürünleri daha ucuza almak hem de ürettikleri malları uygun fiyatlarla satmaktı. Ancak demiryolu inşasının tek sebebi bu değildi. Sanayi Devrimi sonrası, demir sanayii de gelişmiş ve demiryolu yapımında yeni teknolojiler ortaya çıkmıştır. Ancak demiryolu malzemesi ve inşaatı araçları ile lokomotif ve vagon imalatı sanayi düzeyine çıkınca, maliyetleri düşürmek için üretim miktarlarını arttırmak gerektiriyordu. Bu sebeple demiryolu şirketleri yenilikler yapabilmek için ellerindeki eski teknolojiye de müşteri bulmak zorundaydılar. İşte bu noktada Osmanlı İmparatorluğu gibi sanayisini geliştirememiş ülkelerde demiryolları inşa etmek çok karlı bir iş kolu haline gelmişti (H. Kazgan, 1995: 115-116).

Anadolu'da kurulan ilk demiryolu hattı bir İngiliz şirketi tarafindan İzmir- Aydın arasında inşa edilmiştir. Bu güzergâhın seçilmesinin İngilizler açısından çeşitli sebepleri vardı. Bunlardan ilki İzmir-Aydın yöresinin diğer yörelere göre nüfus bakımından kalabalık ve ticari potansiyelinin yüksek olmasıydı. İngiltere'nin pazarı olmaya elverişli etnik unsurların yaşadığı, İngiliz sanayisinin gereksinim duyduğu hammaddeye kolay ulaşılabilecek bir yöreydi. Ayrıca bu bölge, Ortadoğu'nun kontrol altına alınarak, Hindistan yollarının denetim altına alınması bakımında da stratejik bir öneme sahipti. 
Tablo 2: Yabanc1 sermaye ile yapılan demiryolları (\%)

\begin{tabular}{|l|l|l|l|}
\hline Y1llar & Fransa & İngiltere & Almanya \\
\hline 1888 & 12,3 & 63,3 & 3,1 \\
\hline 1914 & 49,6 & 9,8 & 36,8 \\
\hline
\end{tabular}

Kaynak: Pamuk Şevket (1984), Osmanlı ekonomisi ve Dünya kapitalizmi:65-65

Demiryolları yatırımları 1888- 1896 yılları arasında yoğunlaşmışır. Bu dönemde demiryolları imtiyazlarında Alman sermayesi ile Fransız sermayesi arasındaki rekabet dikkat çekmektedir. Bu dönemde İngiltere demiryolları yapımındaki üstünlügünü Fransa ve Almanya'ya kaptırmıştır. Tablo 2'de de görüldüğü gibi İngiltere'nin demiryolu yapımında payı azalırken Fransa ve Almanya’nın payı artmıştır.

Bu iki ülke İmparatorluktaki etki alanlarını arttırmak için demiryolu yapımına girişmiş ve özellikle orta Anadolu'yu dünya pazarına açmışlardır. Alman yatırımları hızlı bir şekilde yayılmasına rağmen, Fransa halen en çok paya sahip olan yatırımcıydı. 1888'de Deutche Bank'ın önderliğinde bir grup, İzmit- Ankara demiryolunun imtiyazını aldığında Fransa hemen Ege'de ve Suriye'de yeni imtiyazlar almak için harekete geçmiştir (Ortayli, age: 72).

Bu iki ülkenin demiryollarını arttırma çabaları mali sorunlarla uğraşan merkezi bürokrasi tarafindan destekleniyordu. Devlet açısından demiryollarının artması sayesinde henüz ekilmemiş bölgelerde tarım yapılabilir ve ihracat artabilirdi. Ayrıca daha fazla tarımsal üretim daha fazla vergi anlamına da geliyordu. Ancak demiryolları merkezi devletin umduğu mali ferahlığ1 sağlayamamıştır (Pamuk, 2005: 80). 1915 yllına kadar Osmanlı Devletinde 6107 kilometrelik demiryolu inşa edilmiş ve bunun 4037 kilometresi yabancı sermayedarlar tarafindan yapılmış ve işletilmiştir. Hükümet kilometre başına belli bir hâsılat garanti ederek yabancı girişimcilerin zarar etmesini engellemiştir (Tezel, age: 87). 1914 yllında Türkiye Cumhuriyetinin sınırları içinde kalan alanda gerçekleşen yabanc1 sermayenin yüzde 57,8 'i demiryollarının inşasına gitmiştir. Bunun yanında bu yatırımların yüzde 4,1'i ticaret, yüzde 4,6's1 liman ve rihtım, yüzde 6's1 madencilik, yüzde 7,5'i sanayi, yüzde 7,8'i belediye hizmetleri, yüzde 11,9'u bankacılık alanlarına yönelmiştir. Madencilik, liman ve rrhtım işletmeciliğinde imtiyazların önemli bir bölümü yabancı devletlerin elindeydi (Sevimay, 1995: 356).

Yabancı sermaye bu dönemde, demiryollarının yanı sıra alt yapı inşasına da yönelmiştir. 1899- 1913 yılları arasında yatırımların yüzde 10’u alt yap1 çalışmalarına gitmiştir. Bu dönemde dışarıya kar transferleri de artmıştır. Her yl yabanc1 sermayedarlar karlarından ortalama 1.3 milyon poundluk bir kısmını Osmanlı toprakları dışına aktarmışlardır ki bu miktar imparatorluğun 
gayri safi milli hasılasının yüzde 1,5'una denk gelmektedir (Pamuk, 1984: 115).

\subsection{Sanayileşmiş ülkelerden alınan diş borçlar}

Batılı Kapitalist devletlerle Osmanlı Devleti arasındaki ilişkilerin bir diğer ayağ1 da dış borçlardır. Osmanlı İmparatorluğu'nun mali sorunlarının çözümü için dış borç alması gerektiği Avrupalı sermayedarlar ve Avrupalı devletler tarafindan 1840'lardan itibaren sik sik hatıllatiliyordu. Ancak Kirım Savaşına (1853- 1856) kadar Osmanlılar Avrupa'dan borç almaya yanaşmadılar. Bu döneme kadar kısa vadeli olarak, az miktarlarda Fransız bankalarından ve çoğunluğunu Rum ve Ermeni asılllıarın oluşturduğu Galata bankerlerinden borç sağlanmıştı (Pamuk, 2005, age: 230). Bu savaş savunma harcamalarını arttırdığı gibi, ciddi nüfus ve toprak kayıplarına sebep olduğu için gelirlerde de azalmaya sebep olmuştur.

Gelir gider dengesinin bozulmasının yarattığı büyük açık sonucunda, 1854 yılında dişarıdan borçlanma sürecini başlamıştır. Bu açıkları gidermek için İngiltere ve Fransa'ya başvurularak 3.300.000 altın Osmanlı lirası borç talep edilmiş ancak ellerine 2.640.000 altın Osmanlı lirası geçmiştir (Dikmen,2005: 140). Bu dönemde İmparatorluğun aldığ1 ilk iki borç Osmanlyy müttefikleri olarak gören İngiltere ve Fransa sayesinde, Galata bankerlerinden alınan borçlardan ucuza gelmiştir (E. Eldem,2005:434). Ancak Osmanlı Devletinin mali sorunları devam ettiği için borçlanmaya devam edilmiştir.

4 Şubat 1863'de imzalanan bir anlaşmayla kurulan Osmanlı Bankası ile özellikle İngiltere ve Fransa'nın Osmanlı Devletine borç vermesi kolaylaşmıştır. Çünkü banka Fransa ve İngiltere adına Osmanlı maliyesi ve hazinesini denetimi altına almış ve tahvillerin bu ülkelerin borsalarında satılması için ön ayak olmuştur. Bu bankanın varlığı Avrupalı sermayedarlara, bankalara, bankerlere ve tasarruf sahiplerine büyük güvence vermiş ve 1863 'den başlayarak Osmanlı İmparatorluğunun bir süre kolay borç bulmasını sağlamıştır (Sevimay, 1995: 290).

İmparatorluğun dış borçlara başvurmasının temel sebebi bütçe açılları, ödemeler bilançosu ve diş ticaret bilançosunun sürekli açık vermesiydi. Osmanlı Devleti, 1854- 1875 yılları arasında 16 kez borç almış ve borçların koşulları giderek ağırlaşmıştır. Alınan borçların büyük bir bölümü eski borçların anapara ve faizlerini ödemek için dışarıya transfer edilmekteydi (G. Kazgan, 2002: 25). Kısa süre sonra Osmanlı Devleti, ödediği yüksek faizlere ve sürekli yeni borçlara ihtiyaç duymasından dolayı anapara ve faizleri ödeyemez hale gelmiştir. 1873'de Avrupa ve Amerika para piyasalarında yaşanan kriz Osmanlı devlet maliyesini zor duruma sokmuştur. Devletin bu koşullar altında yeni borçlar bulması zorlaşmış ve devlet Ekim 1875'de borç ödemelerini yarı yarıya azalttığını açıklamıştır. Bir yl sonra ise Osmanlı 
devleti, tüm borç ödemelerini durdurduğunu ilan etmiştir. Alacaklı ülkeler bu durum karşısında Osmanlı Devletiyle görüşmelere başlamış ve bu görüşmeler 20 Aralık 1881'de Düyun-u Umumiye yani Genel Borçlar İdaresinin kurulmasını ve kısa vadeli borçların azaltılmasını sağlayan Muharrem Kararnamesi2 ile sonuçlanmıştır. Osmanlı idaresi borçları karşılığında gelirlerinin önemli bir kısmını bu idareye teslim etmiştir. 18861914 yılları arasında 26 diş borç sözleşmesi daha yapılmıştır. Bu borçların dördü dişında tümü Düyun-u Umumiye'nin yönetimindeydi. Elde edilen gelirler, esas olarak, eski borçların ödenmesinde ve demiryolu yapıminda kullanılmıştır (Kıray, age:12) Bu borçlar yatırıma dönüştürülemediği için imparatorluğun ekonomik gelişmesine hiçbir katkıda bulunmamıştır.

23 'Temmuz 1908'de ilan edilen Meşrutiyetle birlikte başlayan yenilikler masrafları arttırmıştı. Hali hazırda var olan bütçe açıklarının üzerine bu masraflar eklenince Osmanlı Devletinin dış borç ihtiyacı da artmıştır. 19 Eylül 1908'de bu darboğazı aşabilmek için hükümet Osmanlı Bankası ile bir anlaşma imzalamıştır. Bu anlaşmaya göre 4711124 lira değerinde tahvil ihraç edilmiştir. Karşıllk olarak gümrük gelirlerinden 180000 lira ve Düyunu Umumiye'nin km. teminatı karşılığı tahsil ettiği gelir fazlasından 40000 lira gösterilmiştir. 1914 yllında Trablusgarp ve Balkan savaşları masraflarını karşılayabilmek için Osmanlı Bankasıyla bir anlaşma daha yapmak zorunda kalmıştır. Bu anlaşma sonunda da karşılık olarak Düyun-u Umumiye gelir fazlası, İzmir ve Sivas sancakları aşarları ve Trabzon vilayeti gümrük gelirlerinin bir kısmı gösterilmiştir (Açba, 1995: 119-120). Bu borçlar da Osmanlı Bankası'nın ve Duyun-u Umumiye'nin aracılığıyla alınmış ve Osmanlı Devleti karşılık olarak denetimindeki bütçe gelirlerini göstermiştir.

Osmanlı Devleti dış borçların önemli bir kısmını İngiltere, Fransa ve Almanya'dan almıştır. İlk dönemde İngiliz sermayesinden borç alınmış, 1860'larda ise Osmanlı borçlanmasında Fransız sermayedarlarının payı artmıştır. 1870- 1873 arasında Avusturya sermayesi de piyasaya girmiş ve Osmanlılara borç vermiştir. Düyun-u Umumiye'nin kuruluşundan Birinci Dünya Savaşına kadar geçen süreçte İngiliz sermayesinin aldığ1 Osmanlı istikrazları sınırlı kalmıştır. Bu dönemde Osmanlı Devletinin en çok borçlandığ1 ülke Fransa olmuş ve Osmanlı istikrazlarının önemli bir kısmı Fransız borsalarında satılmıştır. Alman sermayesi ise İngiliz alacaklılarının sattığı istikrazları toplamış ve aynı zamanda 1888'den itibaren Deutche Bank yeni istikrazlar almıştır. Bu koşullar altında Birinci Dünya Savaşına gelindiğinde Osmanlı Devletinin toplam borçlarının yüzde 53’ü Fransa'ya, yüzde 21’i Almanya'ya ve yüzde 14'ü İngiltere'yedir (Pamuk, 2005a age: 81-

\footnotetext{
2 Bu kararname ile Osmanlı borçlarının idaresi, yeni kurulan, yabancılarla ortaklaşa çalışacak olan bir yönetime, Duyunu Umumiye İdaresine birakiliyordu. 1881 yllının Ocak ayında çıkarılıp Muharrem ayında bir fermanla tasdik edilen bu kararname ile 6 yıldır ödemesi durdurulmuş Osmanlı borçları alacaklı ülkelerle uzlaşmaya varılarak bir ödeme planına bağlanmıştır. ( Gürsoy,1984: 20, 32).
} 
85). Eldem'in çalşsmasına göre 1881'de Duyun-u Umumiye kurulduğunda, Osmanlı borçlarının yüzde 40'1 Fransa'ya, yüzde 29'u İngiltere'ye ve yüzde 4,7'si Almanya'ya idi. 1898 yllında İngiltere'nin payı azalırken Almanya'nın payının arttığ1 görülmektedir. Bu yılda borçların yüzde 44,9'u Fransa'dan alınırken, yüzde 10,9'u İngiltere'den, yüzde 12,2'si Almanya'dan alınmıştır. Bu çalışmaya göre 1913'de Fransa'nın payı yüzde 49,5, İngiltere'nin yüzde 6,9, Almanya'nın ise yüzde 20,1 olarak gerçekleşmiştir(V. Eldem, age: 188).

Osmanlı Devleti'nde dış borçların ne durumda olduğunu net görmek için Maliye nazırı Cavit Bey'in 1914 yllı bütçesini ilan ettikten sonra yaptığ1 açılamaları incelemek gerekir. Osmanlı Devleti, özellikle Trablusgarp ve Balkan Harplerinden sonra yeni kredilere ihtiyaç duymuş ve her türlü yolla para aramıştır. Duyun-u Umumiye ve Tütün Rejisinden avans talep etmiş, nispeten küçük miktar için ilkinin imtiyazlarını 25 yıl uzatmışır. Tütün Rejisi ise 1500000 Osmanlı Lirası kredi karşılığında imtiyazlarını 15 yıl uzattırmışıı. Edirne'yi geri alabilmek için paraya ihtiyaç duyan devlet bu koşulları kabul etmiştir. Cavit Bey dış borçlanma konusunda "Avrupalılara kredi için yalvarmak boşunadır. Çünkü dört, beş milyon liralık kredi karşılığında devletin finans kaynaklarını kontrol altına almak istediklerini ben bile birkaç defa duydum. Bu kontrol siyasi kontrolü de getirir. Aynı zamanda askeri kararlarımız konusunda da etkili olmaya başlarlar. Ancak Anadolu'dan yeterli gelir elde etmek mümkün değildir. Tüm dünyaya açıklamak isterim ki eğer kendi topraklarımızdan yeterli geliri elde etmek mümkün olsaydı bu kontrolü kabul etmemiz mümkün olmazdı." şeklinde açılamada bulunmuştur. Bu sözlerine, Mart 1914'de Fransız devletini arkalarına alarak yeni bir kredi anlaşması yapacaklarını ve bu sayede mali sorunlarının üstesinden geleceklerini eklemiştir. Bu dönemde yeni kredi anlaşmaları için Hakkı Paşa Londra'da, Cavit Paşa ise Paris'te görüşmelerde bulunmuşlardır (Fransız Ekonomi ve Finans Bakanlı̆̆ arşivleri, B 0031279/3). Maliye nazırının açıklaması, İttihat ve Terakki Hükümetinin Osmanlı ekonomisindeki yabanc1 kontrolüne karşı yükselen sesleri yumuşatmaya çalıştı̆̆ını ancak finansman için hala dişarıya bağımlı olduğunu göstermektedir.

\section{Osmanlı İmparatorluğundaki Fransız Yatırımları ve D1ş Borçlar}

Osmanlı İmparatorluğunda Fransız sermayedarlarının yatırımlarını ve verilen borçları incelemeden önce Fransız ekonomisinin gelişimine bakmakta yarar vardır. Fransa sanayileşmeye 19. yüzyllın başlarında başladı. 18. yüzyllda Fransız devrimi ve diğer savaşlar sebebiyle ekonomik gelişme de İngiltere'nin gerisinde kald1. 1815-48 döneminde, Fransız ekonomisi 18. yüzylla göre daha hızlı büyümüştür. 19. yüzyılın ikinci yarısında ekonomik büyüme dalgalı bir seyir izlemiştir. 1848-51 döneminde siyasi ve ekonomik krizlerle karşı karşıya kalınsa da, 1851-1881 döneminde Fransa’nın servet ve 
geliri yüzyıl boyunca ulaştığ1 en yüksek seviyeye gelmiştir (Güran, 2014: 182183).

Fransa sanayi dönüşümünü gerçekleştirdikten sonra sömürgeleşme yarışına girmiştir. Sömürge haline getirdiği ülkelerde demiryolu yatırımlarıyla birlikte diğer alanlarda da yatırımlar yapmıştır. Aynı zamanda bu ülkelere borçlar da vermiştir. Osmanlı İmparatorluğu toprakları üzerindeki rekabet sonucu burayı sömürge haline getiremese de, bu rekabette önemli bir yere sahip olan ülkelerden birisi de Fransa'dır. Fransa özellikle 1898-1918 y1llar1 arasında Osmanlı topraklarındaki etkisini arttırmak için yoğun şekilde uğraş vermiştir. Bu dönemde Fransa'nın etkisi ekonomik alanda artmış, Fransız bankalarının ve sermayedarlarının, Osmanlı topraklarıyla ilgili üretilen politikalarda daha fazla söz sahibi olmuşlardır (Fulton, age:137) .

Fransa'nın bu topraklar üzerinde etkisini arttırmak için yaptığı çalışmalar da, 1888 yılından sonra özellikle Almanya ile olan rekabet öne çıkmıştır. Kullanılan arşiv belgelerinde Fransız devletinin de bu topraklarda Fransız etkisinin artması için yatırımcıları desteklediği anlaşılmaktadır.

\subsection{Fransızların yaptığı demiryolları ve diğer yatırımlar}

1888 yılından Birinci Dünya Savaşına kadar ki dönemde, Fransa'nın Osmanlı Devletindeki yatırımlarında başta demiryolu yapımı olmak üzere önemli bir artış olmuştur. İlk dönemlerde Fransız yatırımcıların Anadolu topraklarında demiryolu inşasıyla uğraşmaları biraz yavaş olmuştur. İzmir'den başlayan ilk iki demiryolu İngilizler tarafından yapılmıştır. Fransız yatırımcılarının bu işe ilk katılımları Fransız- İngiliz ortaklığı ile yapılan Mersin- Tarsus- Adana hattı ve Fransız- Belçika ortaklığı ile yapılan Mudanya- Bursa hattıyla olmuştur (Thobie, 1977: 137).

1888-1896 yilları arasinda Fransa ile Almanya arasinda bu topraklarda ciddi bir rekabet olmuştur. Alman ve Fransız sermayesi İmparatorluğu etki alanlarına almak için bölgelere ayırmıs ve yoğun olarak demiryolları yapımına girişmişlerdir. Almanya Osmanlı topraklarında sahneye 1898 y1lında Alman imparatoru II. Wilhelm'in Osmanlı İmparatorluğuna yaptığ1 resmi ziyaretle çıkmıştır. Demiryollarıyla Anadolu'nun içlerine kadar ulaşmışlar ve bu toprakları da dünya ticaretine açmışlardır. Almanya Bağdat demiryollarını yapmak için Osmanlı Hükümetinden imtiyaz alınca Fransızlar Almanlarla uzlaşma yoluna gitmişler 1903 yılında kurulan Bağdat Demiryolları Şirketinin sermayesinin yüzde 30'una katılmışlardır (Georgeon, 2016: 701-702). Aynı zamanda Fransizlar, 1888'den sonra Almanya'dan daha fazla demiryolu yapmıştır. Birinci Dünya Savaşı öncesi Osmanlı topraklarında en çok demiryolu yatırımı yapan ülke Fransa olmuştur (Pamuk, 2005a, age: 74-75).

Fransız sermayesi demiryollarının yanı sira su, gaz gibi belediye hizmetlerine, bankacılık ve ticarete de yatırım yapmıştır. 1895 yılı verilerine göre Fransız yatırımlarının yüzde 31,2'si banka, yüzde 42,5’i demiryolu, 
yüzde 11,2'si liman, yüzde 1,1'i maden, yüzde 11,8’i hizmet sektörü ve yüzde 2,2si diğerleriydi. 1914 yllına gelindiğinde hizmet sektörü yatırımları dışında diğerlerinde bir miktar azalma olmuştur (Thobie, age: 480).

1888'de Fransızların, Osmanlı topraklarındaki demiryolu yatırımları toplam demiryolu yatırımlarının yüzde 12,3 iken bu oran 1914 yilında yüzde 49,6'ya ulaşmıştır ve sonuç olarak 2 Ağustos 1910'da İstanbul'daki Fransız maslahatgüzarı M. Boppe'un, Dışişleri bakanı M. Stephen Pichon'a gönderdiği mektupta Osmanlı İmparatorluğunda, Fransız yatırımcilar tarafindan yapılacak yeni demiryollarından bahsedilmiştir. Bu belgeye göre 20 Temmuz 1910 tarihinde Fransız yatırımcilar ile Fransız Bayındırlık Bakanlığı arasında Osmanlı topraklarında demiryolu yapımı için bir anlaşma imzalanmıstır. Yeni yapılacak olan demiryolları Anadolu'nun en zengin bölgelerini birleştirecektir. Bu hatlar İzmir'den Sivas'a ve Bursa'dan Adana'ya uzanacaktır. Aynı zamanda Suriye ve Arnavutluk'ta da çalışmalar yapılacaktır. Bu inşaatın bitiş tarihi olarak Mart 1912 öngörülmüştür. İnşaata başlamadan önce Fransız sermayedarlar hatların geçtiği yerlerdeki iş olanakları hakkında tam bilgi edinememiş olsalar da bu bölgelerden iyi kar elde edeceklerini düşünmüşlerdir. Fransız devleti de bu demiryolları sayesinde bu topraklardaki etkisinin artacağını düşünmektedir. Bu nedenle M. Boppe bu çalışmalardan dolayı Fransız sermayedarları ve Bayındırlık Bakanlığındaki teknik ekibi kutlamamız lazım diye yazmıstır (Fransız Ekonomi ve Finans Bakanlığı arşivleri, B 0031287/5).

1888'den sonra Osmanlı topraklarında demiryolları yapımı konusunda iki ülke arasındaki rekabet kızışmıştır. Bu konuda 17 Aralık 1913'de Paris'te hazırlanan ve Osmanlı İmparatorluğundaki demiryolları için verilecek borçları açılayan bir bilgilendirme notu ilginçtir. Bu nota göre 20 Temmuz 1910'da bir Fransız şirketinin Alman Büyükelçiliğinin itirazlarına rağmen yeni demiryolu yapımı için hükümetle anlaşmıştır. Ancak İtalya ile Osmanlı arasındaki savaş, iki Balkan Harbi ve Yunan- Türk savaşı nedeniyle demiryolunun yapımı gerçekleşememiştir. Fransız şirketini düştüğü zor durumdan kurtarmak için la Banque Française pour le Commerce et l'Industrie (Fransız Ticaret ve Endüstri Bankası), Fransız Devletinin onayılla Osmanlı Devletine borç vermiştir. Bu nota göre şirketin Osmanlı topraklarında 250 tane mühendisi bulunmaktadır. Tüm vilayetlerde ağırlığını hissettiren bu mühendisler ve inşa ettikleri yollar sayesinde doğuda Fransız etkisi artmaktadır. Bu nedenle yeni borçlar verilmeli ve bu şirket zor durumdan kurtarılmalıdır. Notta eğer Osmanlı topraklarında demiryolu yapımına ara verilirse Fransa'nın doğudaki itibarı yerle bir olacağ1 vurgulanmıştır. Bilgilendirme notundan anlaşıldığı üzere, Fransız Devleti bu bölgedeki etkisini kaybetmemek için sermayedarlarının yaptığı yatırımları yakından izlemiş ve korumuştur. 
Demiryollarının yanı sıra aynı dönemde Fransız sermayesi Osmanl topraklarında dolaysız yatırımlarda yapmıştır. 1888-1896 yılları arasında Osmanlı Devletine yapılan dolaysız yatırımlar incelendiğinde de Fransa ile Almanya arasındaki rekabeti görmek mümkündür. Bu dönemde hem Fransa hem de Almanya'dan gelen sermaye Osmanlı ödemeler dengesini olumlu yönde etkileyecek miktarlardadır. Bu rekabete rağmen Fransız sermayesi Alman sermayesine göre daha fazla yatırım yapmıştır. 1896 yılından sonra ise her iki ülkenin sermayedarları da getirdiklerinden daha fazlasını kar aktarımı biçiminde dışarıya çıkarmışlardır (Pamuk, 2005a, age: 90-91).

Fransız sermayedarlarının yöneldiği bir başka alan da sigortacılıktır. 1914 yılında, bu alandaki toplam yatırımların yüzde 81,8’i Fransa'ya aittir. Aynı yıl ticarette de Fransız yatırımlarının yoğun olduğu görülmektedir ve bu alandaki toplam yatırımların yüzde 70,7'si Fransa tarafindan gerçekleştirilmiştir. Aynı şekilde madencilik ve bankacıllı alanında da en fazla sermaye Fransa tarafindan Osmanlı Devletine getirilmiştir. Fransız sermayesinin Osmanlı İmparatorluğunda birçok bölgede etkili olması ve demiryolları ile birlikte diğer alanlarda yatırımlar yapabilmesinde Osmanlı Bankasının etkisi çok fazla olmuştur. Bu banka İngiliz sermayesinin bu bölgede göreli önemini yitirmesiyle, Fransız sermayedarlarının çıkarlarını korumaya başlamıştır (Pamuk, age:74-86).

9 Nisan 1914'de, Osmanlı Devleti ile Fransa arasında yapılan anlaşmada Kapitülasyonların yanı sıra Fransız yatırımları da yer almıştır. Anlaşma Fransiz basınında da yer bulmuştur. 15 Nisan 1914 L'Express Finance isimli dergide çıkan makaleye göre, bu anlaşma iki ülke açısından oldukça önemlidir. Ancak yeterince mükemmel değildir çünkü yapılan anlaşmayla Fransa, Osmanlı Devleti'nden alabileceğinin tamamını elde edememiştir. Fransa, Ermeni ve Suriye bölgelerinde önemli demiryolu ayrıcalıkları almıştır aynı zamanda Akdeniz ve Karadeniz'de limanlara sahip olmuştur. Bunun karşılığında Osmanlı Devleti de Fransa'dan yeni borçlar almış ve finansal açıdan bazı kolaylıklar elde etmiştir. Bu anlaşma ile Fransız ordusunun Midilli'ye gelmesi sonucu iki ülke arasında yaşanan olumsuzluklar da ortadan kalkmıştır. Yine bu dergideki yoruma göre bu anlaşma sayesinde 1910 yılından itibaren Osmanlı topraklarında etkisini kaybeden Fransa yeniden eski haline dönecektir. Özellikle Almanya ile olan ilişkilerini dengelemek isteyen Osmanlı bürokratları, Fransa ile Osmanlı arasındaki ilişkileri düzeltmek istemektedirler ve bu anlaşma bu duruma ön ayak olacaktır. Ayrıca Fransa'da bir an önce zengin Anadolu topraklarındaki etkisini arttırmalıdır (Fransız Ekonomi ve Finans Bakanlığı arşivleri, B 0031281/2). Derginin yorumlarında anlaşıldığ1 üzere, Osmanlı İmparatorluğunun Almanya'ya yönelmiş olması belli ki Fransa'da bazı çevrelerde rahatsızlık yaratmıştır. 


\subsection{Fransa'dan alınan borçlar}

Osmanlı Devleti ile Fransa arasındaki ekonomik ilişkilerin bir başka boyutu da Osmanlı’nın dış borçlarıdır. 1888- 1914 döneminde, bu borçlarda önemli bir artış meydana gelmiştir. Avrupalı devletler, Osmanlı Devleti'ndeki yaptıkları yatırımlarından daha fazla borç vermişlerdir. İmparatorluğun, ekonomik durumu bu dönemde kalıc1 zayıflık ve bu zayıflığı ağırlaştırıcı olayları içerir. İmparatorluk, sürekli uygun faizli borç bulmaya çalışışıtır (Thobie, age:222). 19. yüzyılın ortalarından itibaren Osmanlı Devleti borç bulmaya çalışırken, Fransızların elindeki sermaye fazla ve bu ülkede faizler de düşük olduğundan dolayı Fransız yatırımcılar paralarını yurt dışında değerlendirmeyi tercih etmişlerdir. Bu dönemde Osmanlı devletine borç vermek de oldukça karlı bir yatırım olmuştur (Raccagni, age:344).

1914 yılında Osmanlı dış borçlarında yüzde 53’ü̈k payla en önemli kaynak Fransa'dır. Ancak aynı dönemde Fransa'nın Rusya ile ekonomik ilişkileri artmış ve bu pazardaki çıkarları Osmanlı pazarının önüne geçmeye bașlamıștır. Özellikle Fransa'nın Osmanlı Devletine silah sağlaması Ruslar tarafinda olumlu karşıllanmamıştır. Rusya'nın etkisiyle Fransa, Birinci Dünya Savaşı öncesi Osmanlı tahvillerinin Fransız borsalarında satışa çıkarılmasını, elde edilecek gelirin askeri harcamalar için kullanılmaması şartı ile kabul etmiştir. Bu ön koşullar Fransa'nın Osmanlı Devleti üzerindeki etkisini azaltmış ve Almanya'yı öne çıkartmıştır (Pamuk, 2005a, age: 91).

$\mathrm{Bu}$ durum Fransa'daki gazetelerde çıkan haberlerde de kendini göstermektedir. 27 Ocak 1914'de La Vie Financiére isimli gazetede Cavit Bey'in Paris'teki görüşmeleriyle ilgili yayınlanan makaleye göre, bu görüşmeler Türk halkı ve basınında kızgınlığa sebep olmuştur. Osmanlı Devleti'nin aldığı yeni borçlar bu kızgınlığı azaltmamıştır çünkü bunun karşıllğında Fransız hükümeti Osmanlı devletine, barışın devam edebilmesi için Ermeni bölgesinde Rusların istediği reformlanı gerçekleştirmeleri gerektiğini söylemiştir. Makaledeki yoruma göre Fransa, bu bölgedeki çlkarlarına ters bir duruş sergilemekte ve Osmanlllardan gururlarını incitecek şeyler istemektedir. Fransa'nın bu bölgede başarısız olması durumunda Osmanlı devletinin, Alman kaynaklarına yönelme tehlikesi vardı.

Nitekim Türk basınında da Osmanlı Devleti'nin farklı kaynaklara yönelebileceği haberlerine yer verilmekteydi. Tanin gazetesinde çıan habere göre Fransa, Osmanliya pazarını kapatırsa, devlet yeni alternatifleri değerlendirmek zorunda kalacaktır. Ya da eğer Fransa'dan gelen borçlar kesilirse, farklı kaynaklara yönelebilirdi. Gazeteye göre Fransa, Avrupa'nın en büyük finans kaynağıdır ama tek kaynak değildir. Amerika Birleșik Devletleri önemli bir güç olarak Fransa'nın karşısına çıkmaktadır. La Vie Financiére'deki habere göre benzer yorumlar Osmanlıdaki diğer gazetelerde de yer almaktadır. O nedenle bu haberleri görmezden gelmek mümkün 
değildir. Dergideki habere göre eğer Fransa, yeterli kaynak ayırmazsa, Osmanlı Devleti’nin de farklı ülkelerden kredi bulması mümkündür ve bu başarısızlık Fransa'nın doğudaki çıkarlarını olumsuz etkileyecektir (Fransız Ekonomi ve Finans Bakanlığ1 arşivleri, B 0031281/2). Bu habere göre Fransa vereceği borçlara karşılık Rusya'nın haklarını korumaya ve Osmanlı devletine bu konuda müdahale etmeye çalışmıştır. Bu durum Osmanlı yöneticilerinin ve Türk basınının Fransa'yı eleştirmelerine sebep olmuştur. $\mathrm{Bu}$ dönemde Fransız hükümeti, Osmanlı ve Rus pazarındaki çıkarları arasında kalmıştır.

Fransız Devleti bu bölgedeki etkisini kaybetmek istememiş olmalı ki Cavit Bey'in Paris ziyareti sonrası, 9 Nisan 1914'de iki ülke arasında yapılan anlaşmada Osmanlı borçları da yer almıştır. Osmanlı İmparatorluğu 1914 yılında borçlarının yüzde 5'ini ödeyebilmek için 800 milyon franklık borç istemiştir. Bu ödeme Duyun-u Umumiye tarafindan yapılacaktır. Aynı zamanda Osmanlı Bankası da Nisan sonunda piyasaya 500 milyon değerinde para sürecektir. Daha sonraki bir tarihte yeni bir miktar para daha piyasaya sürülecektir. $\mathrm{Bu}$ teminatlar sayesinde Fransa borç vermeyi kabul etmiştir. Aynı zamanda aynı teminatlar geçerli olursa, Fransız şirketlerinin demiryolu ve diğer alt yapı çalışmalarını yapmalarına da karşı çıkılmayacaktır (Fransız Ekonomi ve Finans Bakanlığı arşivleri, B 0031281/2).

Birinci Dünya Savaşı öncesi Fransız yatırımcılar diğer rakip devletlere rağmen oldukça etkilidirler. Fransız Devleti özellikle demiryolu yatırımlarını ve diş borçları bu bölgede etkisini artıran ekonomik yatırımlar olarak görmektedir. Fransa, özel sektörün yaptığ1 yatırımları yakından izlemiş ve sorun çıktığında müdahale etmiştir. Rusya'daki çıkarları savaş öncesi öne çıkmaya başlasa da Osmanlı pazarını kaybetmek istememiştir. Aynı zamanda özellikle demiryolu yapımı konusunda imtiyazlardan yararlanmak için Almanya ile sıkı bir rekabete girmiştir. Birinci Dünya Savaşı öncesi, yabancı yatırımlar ve dış borçlar açısından Fransa Osmanlı topraklarındaki en güçlü Kapitalist Devlet olmuştur.

\section{Sonuç}

Sanayi Devrimi sonrası yeni pazar arayışına giren Kapitalist Devletlerin yöneldikleri ülkelerden biri de Osmanlı İmparatorluğu olmuştur. Batıda yaşanan bu değişimi yakalayamamış olan Osmanlılar, önce ticaret daha sonra demiryolları, dolaylı yatırımlar ve borçlanma ile pazarlarını sanayileşmiş devletlere açmıştır. Fransa da bu pazarda önemli yere sahip devletlerden biridir. Birinci Dünya Savaşı öncesi Osmanlı ticaretindeki payı İngiltere'nin gerisinde kalsa da yatırımlar ve verilen borçlar açısından bu pazardaki en etkili devlet olmuştur. Fransa, 1888 yilından sonra özellikle demiryollarının inşası konusunda Almanya ile rekabete girmiş olsa da, bu dönemde en fazla demiryolu imtiyazını almıştır. Kullandığımız arşivler göstermektedir ki Almanya'nın etkisi artarken, Fransa da avantajlı durumunu kaybetmemek 
için uğraşmıştır. Osmanlı Devleti de savaş öncesi kapitülasyonları azaltıp ekonomisindeki yabancı etkisini azaltmaya çalışsa da ihtiyacı olan borçlar dolayısıyla yeni imtiyazlar vermek durumunda kalmıştır. Yeni finans kaynakları elde edebilmek için Fransa'yla olan yakın ilişkilerini sürdürmeye gayret etmiştir. Elimizdeki arşiv belgelerinde de anlaşıldığı üzere Fransız Devleti de bu pazarı elinden kaçırmamak için uğraş vermiş, rakip devletler karşısında bu bölgedeki çıkarlarını korumuştur. Savaş öncesi, doğudaki etkisini korumak için Osmanlı Devletiyle ekonomik ilişkilerini güçlü tutmuş̧tur. 


\section{Kaynakça}

LES ARCHIVES ECONOMIQUES ET FINANCIERES (Fransiz Ekonomi ve Finans Bakanluğ1 Arşivleri) Dosya no: B 0031281/2, B 0031287/5, B 0031279/2, B 0031279/3

AÇBA S. (1995) Osmanlı Devletinin Dış Borçlanması (1854- 1914), Afyon Kocatepe Üniversitesi Yayınları, Afyon

DİKMEN N. (2005) "Osmanlı Dış Borçlarının Ekonomik ve Siyasi Sonuçlar1”, s: 137-159,Atatürk Üniversitesi İktisadi ve İdari Bilimler Dergisi, Cilt 19, Say1:2, Eylül, Erzurum

ELDEM V. (1994) Osmanlı İmparatorluğunun İktisadi Şartları Hakkında Bir Tetkik, Türk Tarih Kurumu Yayınları, Ankara

ELDEM E. (2005) "Ottoman financial integration with Europe: foreign loans, the Ottoman Bank and the Ottoman public debt", European Review, vol.13, no.3, 431-445, Academia Europaea, United Kingdom

GEORGEON F. (2016), “Son Canlanış (1878-1908)”, Osmanlı Imparatorluğu tarihi, Robert Martran, Çeviren Server Tanilli, Türkiye İş bankası Kültür yayınları, 3. Basım, İstanbul

GÜRAN T. (2014) İktisat Tarihi, DER Yayınları, İstanbul

GÜRSOY B. (1984) 100. Yllinda Düyun u Umumiye İdaresi Üzerinde Bir Değerlendirme, İstanbul Üniversitesi İktisat Fakültesi Mecmuas1, İstanbul

FULTON L. B. (2005) "France and the end of Ottoman Empire", The great Powers and the end of the Ottoman Empire, Edited by Marian Kent, Frank Cass, London

KAZGAN G. (2002) Tanzimat'tan 21. Yüzy1la Türkiye Ekonomisi, İstanbul Bilgi Üniversitesi Yayınları, İstanbul

KAZGAN H. (1995) Osmanlida Avrupa Finans Kapitali, Yap1 Kredi Yayınlar1, İstanbul

KIRAY E. (1995) Osmanlı'da Ekonomik Yap1 ve Dış Borçlar, İletişim Yayınları, İstanbul

ORTAYLI İ. (2008) Osmanlı İmparatorluğu'nda Alman Nüfuzu, Timaş Yayınları, İstanbul

PAMUK S.. (1984) The Ottoman Empire in The "Great Depression" of 1873-1896 The Journal of Economic History, Vol. 44, No. 1, 107 118, Cambridge 
PAMUK Ş. (1984) Osmanlı Ekonomisi ve Dünya Kapitalizmi (1820-1913), Yurt yayınevi, Ankara

PAMUK Ş. (2005a) Osmanlı Ekonomisinde Bağımllık ve Büyüme 18201913, Tarih Vakfi, İstanbul

PAMUK Ş. (2005) Osmanlı Türkiye İktisadi Tarihi 1500- 1914, İletişim Yayınlar1, İstanbul

RACCAGNI M. (1980) The French Economic Interests in The Ottoman Empire, Int. J. Middle East Stud. II, 339-376

SEVIMAY, R.S. (1995) Cumhuriyete Girerken Ekonomi Osmanlı Son Dönem Ekonomisi, Kazancı Kitap Tic. A.Ş. İstanbul

TEZEL S. Y. (2002), Cumhuriyet Döneminin İktisadi Tarihi, Tarih Vakfi Yurt Yayınları, İstanbul

THOBİE J. (1977), Intérets et impérialisme français dans l'empire Ottoman (1895-1914), 1. Cilt, Paris 1 Pantheon-Sorbonne yayınlar1, Paris 